\begin{tabular}{|l|l|l|l|}
\hline $\begin{array}{l}\text { Eiszeitalter und Gegenwart } \\
\text { Quaternary Science Journal }\end{array}$ & $\mathbf{5 7 / 3 - 4}$ & $367-381$ & Hannover 2008 \\
\hline
\end{tabular}

\title{
Sediment Input into the Heidelberg Basin as determined from Downhole Logs
}

\author{
SABine HunZe \& Thomas WoniK*
}

\begin{abstract}
The Upper Rhine Graben, and the Heidelberg Basin in particular, play an important role in the investigation of climate change and tectonic activity during the Tertiary and Quaternary periods. Several research boreholes were recently drilled to acquire data for a new interpretation of the geology of the northern Upper Rhine Graben. This paper investigates in detail the boreholes at Heidelberg, Viernheim and Ludwigshafen-Parkinsel, as well as the shallower boreholes at Pfungstadt, Stadtwerke Viernheim and Hüttenfeld, in terms of their geophysical parameters. The physical properties of the lithologies described in the cores are characterised on the basis of borehole logging data. A hole-to-hole correlation between adjacent boreholes is then conducted, using the characteristic changes in the 'natural radioactivity' parameter to acquire information on changes in sediment provenance (Rhine, Neckar, Pfälzerwald and Odenwald). An interpretation applying the statistical method of cluster analysis allows identification of sections with homogenous physical properties from downhole measurements and thus the determination of possible sediment provenance.
\end{abstract}

\section{[Interpretation des Sedimentationsgeschehens im Heidelberger Becken anhand von Bohrlochmessun- gen]}

Kurzfassung: Der Oberrheingraben und insbesondere das Heidelberger Becken spielen eine Schlüsselrolle bei der Untersuchung der Änderungen im Klima und der tektonischen Aktivitäten im Tertiär und Quartär. In den letzten Jahren wurden einige Forschungsbohrungen abgeteuft, um Daten für eine neue Interpretation der Geologie des nördlichen Oberrheingrabens zu erhalten. Im Rahmen dieser Arbeit werden die Bohrungen Heidelberg, Viernheim und Ludwigshafen-Parkinsel sowie die flacheren Bohrungen Pfungstadt, Stadtwerke Viernheim and Hüttenfeld anhand der dort durchgeführten geophysikalischen Bohrlochmessungen näher untersucht. Die physikalischen Eigenschaften der einzelnen an den Kernen beschriebenen Lithologien werden mit Hilfe der Daten der Bohrlochmessungen charakterisiert. Anschließend erfolgt eine Korrelation zwischen benachbarten Bohrlöchern, um aus den charakteristischen Änderungen im Parameter ,natürliche Radioaktivität' Aussagen zur Änderung der sedimentären Liefergebiete (Rhein, Neckar, Pfälzerwald und Odenwald) zu treffen. Eine Auswertung mit der statistischen Methode der Clusteranalyse ermöglicht es, aus den Bohrlochmessungen Bereiche mit einheitlichen physikalischen Eigenschaften zu finden und damit die möglichen sedimentären Liefergebiete einzugrenzen.

Keywords: Heidelberg Basin, downhole logging, hole-to-hole correlation, sediment provenance

* Addresses of authors: S. Hunze, T. Wonik, Leibniz Institute for Applied Geophysics, Stilleweg 2, 30655 Hannover, Germany. E-Mail: sabine.hunze@liag-hannover.de, thomas.wonik@liag-hannover.de 


\section{Introduction}

\subsection{Geology}

One of Europe's largest river systems, the River Rhine, provides a unique geoscientific data set with the potential of bridging the gap between glaciated alpine areas and the inland ice-sheet advances of Northern Europe (WesterhofF 2008). The Upper Rhine Graben extends approximately $300 \mathrm{~km}$ from Basel (Switzerland) to Frankfurt (Germany) and is $35-45 \mathrm{~km}$ wide on average. This graben is a north-northeasttrending rift of Tertiary age (ELLWANGER et al. 2005). As a subsidence structure it forms an element of the Oligocene and Neogene rifting of the Upper Rhine Graben, representing $40 \mathrm{Ma}$ of active graben tectonics (BEHRMANN et al. 2003). The Oberrhein (Upper Rhine) Valley, as a graben structure, forms part of the rifting system that began to develop during the mid-Tertiary (Preusser 2008). During the Quaternary, the subsiding part of the northern Upper Rhine Graben acted as a distal and final accommodation space for coarser alpine material (ELLWANGER et al. 2005).

Rhine sediments have recorded changes in both climate and tectonic activity (Preusser, 2008). During the Pliocene-Quaternary, the major subsidence centre shifted towards the eastern part of the graben (Heidelberg Basin), with a zone of maximum subsidence located in the centraleastern part of the basin, around the city of Heidelberg (Ellwanger et al. 2005). The Pliocene-Quaternary infill of the Heidelberg Basin was mainly deposited by the River Rhine. The most distal signals of alpine climate dynamics associated with the major events of alpine glaciation can still be identified as sediment bodies within the Pleistocene succession. They are embedded in relatively fine alpine material and coarser local material. Coarser layers are also present, which are related to sediment input from the River Neckar (Ellwanger et al. 2005). Towards the north, the character of the graben sediments change as a result of sorting processes during fluvial transport and admixture with local material derived from the graben margins. In the northern part of the Upper Rhine Graben the graben sediments are generally finer grained, better sorted and mixed with local sediment input from the graben margins (HAGEDORN \& BoENIGK 2008).

\subsection{Boreholes}

Recently, numerous boreholes have been sunk to acquire new data for reinterpreting the geology of the northern Upper Rhine Graben. These research boreholes are at Heidelberg, Viernheim and Ludwigshafen-Parkinsel (hereinafter called Ludwigshafen for short); shallower local boreholes are located at Pfungstadt, Stadtwerke Viernheim and Hüttenfeld (Figure 1 and Table 1). The borehole at Viernheim documents the conditions at the centre of the basin and those in Ludwigshafen and Heidelberg the western and eastern margins of the basin facies. Ludwigshafen and Viernheim represent the succession of Rhine sediments, but both also include signals from non-rhine sedimentation: small rivers from Pfälzerwald in Ludwigshafen, Neckar sediments in Viernheim. The borehole in Pfungstadt is located at the northern margin of the Heidelberg Basin.

The most significant parameters of the investigated sites are given in Table 1. The geological surveys of Hessen, Baden-Württemberg and Rheinland Pfalz, respectively, are in charge of the investigated boreholes. The drilling depth varies significantly between the sites: the deepest boreholes are at Viernheim and Ludwigshafen (350 $\mathrm{m}$ and $300 \mathrm{~m}$ respectively) and the shallowest at Hüttenfeld $(99 \mathrm{~m})$. Overall core recovery is very high (81-99\%). The only exception is the borehole at Hüttenfeld, where only cuttings were analysed and documented. The depth reached by downhole measurements differs from the total depth due to borehole and technical problems.

The position of the Pliocene/Pleistocene boundary within these deposits, as well as the entire stratigraphy of the Upper Rhine Graben, is rather controversial (cf. ELLWANGER et al. 1995; Fetzer et al. 1995; GibBard 2004; GibBARD et al. 2005; Clague 2006). The boundary 


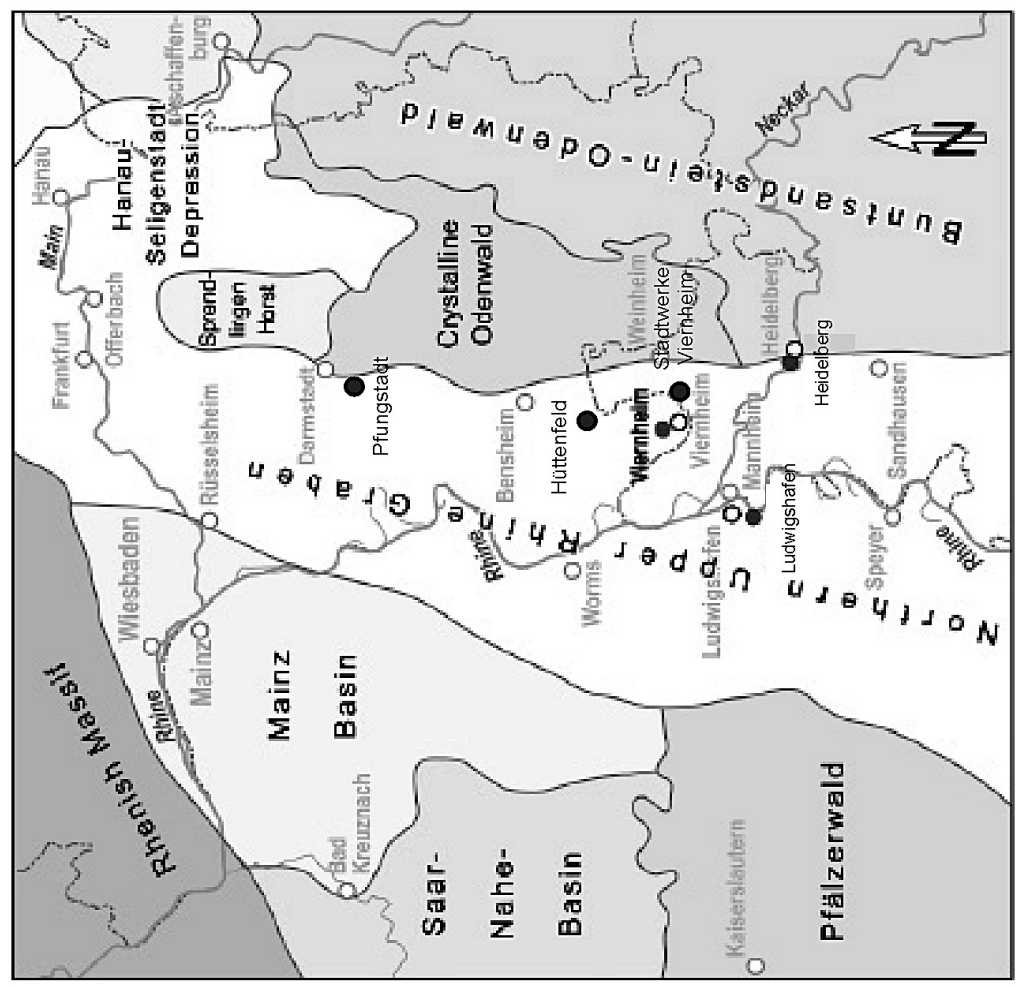

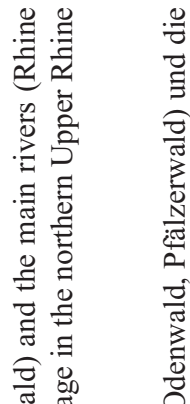
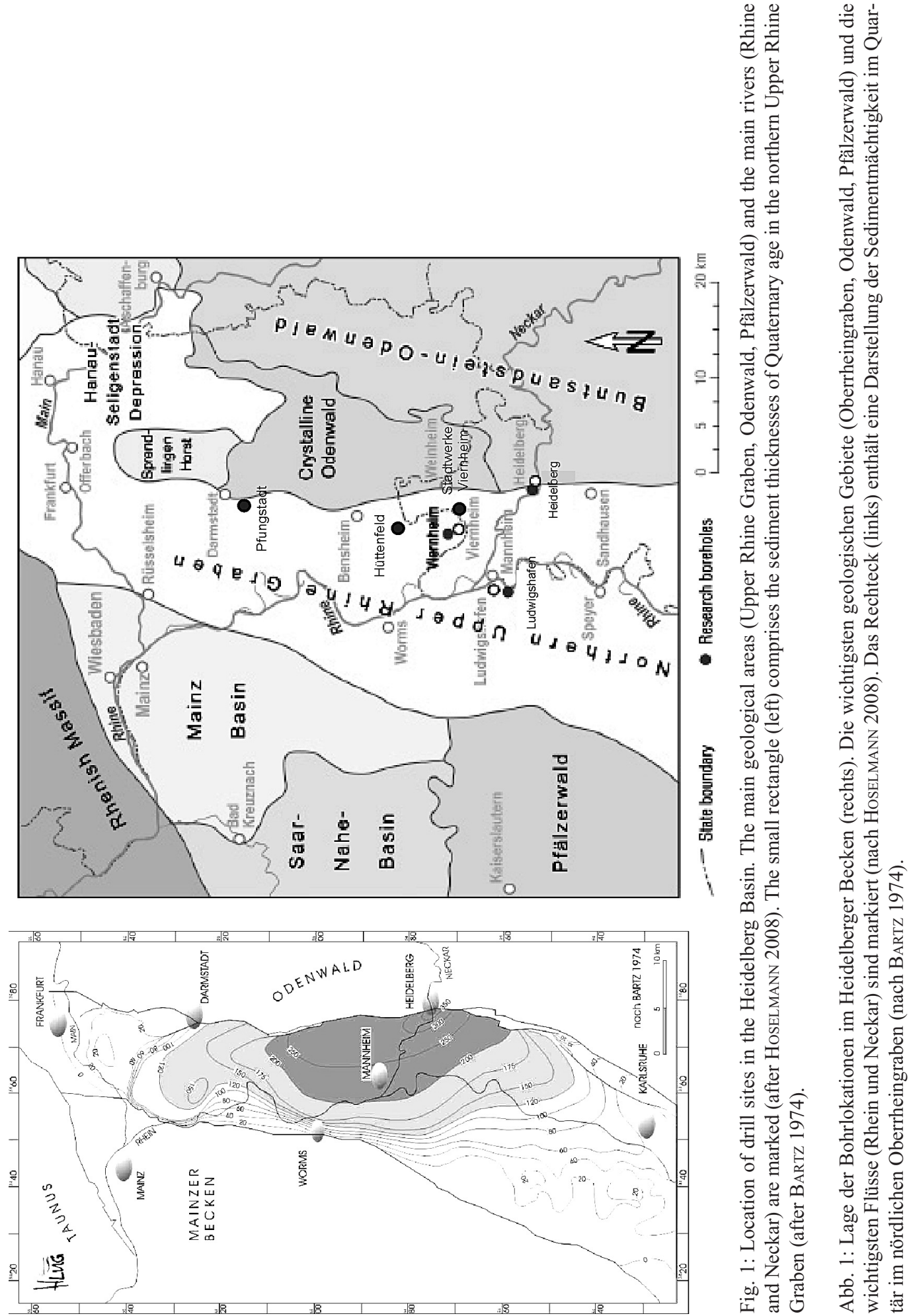
Table 1: Basic parameters of the investigated boreholes.

Tab. 1: Grundlegende Parameter der untersuchten Bohrungen.

\begin{tabular}{|c|c|c|c|c|c|c|}
\hline & Pfungstadt & Hüttenfeld & Viernheim & $\begin{array}{l}\text { Stadtwerke } \\
\text { Viernheim }\end{array}$ & Heidelberg & $\begin{array}{l}\text { Ludwigs- } \\
\text { hafen }\end{array}$ \\
\hline $\begin{array}{l}\text { Responsible } \\
\text { operating } \\
\text { institution }\end{array}$ & $\begin{array}{l}\text { Geological } \\
\text { Survey } \\
\text { (HLUG) } \\
\text { Hessen }\end{array}$ & $\begin{array}{l}\text { Geological } \\
\text { Survey } \\
\text { (HLUG) } \\
\text { Hessen }\end{array}$ & $\begin{array}{l}\text { Geological } \\
\text { Survey } \\
\text { (HLUG) } \\
\text { Hessen }\end{array}$ & $\begin{array}{l}\text { Geological } \\
\text { Survey } \\
\text { (HLUG) } \\
\text { Hessen }\end{array}$ & $\begin{array}{l}\text { Geological } \\
\text { Survey } \\
\text { (LGRB) } \\
\text { Baden- } \\
\text { Württemberg }\end{array}$ & $\begin{array}{l}\text { Geological } \\
\text { Survey } \\
\text { (LGB-RLP) } \\
\text { Rheinland- } \\
\text { Pfalz }\end{array}$ \\
\hline Drilling depth & $200 \mathrm{~m}$ & $99 \mathrm{~m}$ & $350 \mathrm{~m}$ & $110 \mathrm{~m}$ & $180 \mathrm{~m}$ & $300 \mathrm{~m}$ \\
\hline Core recovery & $98 \%$ & $\begin{array}{l}\text { Drill } \\
\text { cuttings }\end{array}$ & $97 \%$ & $99 \%$ & $81 \%$ & $99 \%$ \\
\hline $\begin{array}{l}\text { Basis of } \\
\text { Quaternary }\end{array}$ & At $132 \mathrm{~m}$ & $\begin{array}{l}\text { Not } \\
\text { recovered }\end{array}$ & At $225 \mathrm{~m}$ & $\begin{array}{l}\text { Not } \\
\text { recovered }\end{array}$ & Not recovered & At $177 \mathrm{~m}$ \\
\hline $\begin{array}{l}\text { Downhole } \\
\text { logging }\end{array}$ & To $180 \mathrm{~m}$ & $\begin{array}{l}\text { To } 75 \mathrm{~m} \text {, } \\
\text { only GR }\end{array}$ & To $238 \mathrm{~m}$ & $\begin{array}{l}\text { To } 108 \mathrm{~m} \text {, } \\
\text { only GR }\end{array}$ & To $180 \mathrm{~m}$ & $\begin{array}{l}\text { To } 300 \mathrm{~m} \text {, } \\
\text { only GR }\end{array}$ \\
\hline
\end{tabular}

between Pliocene and Quaternary strata has been defined by the first occurrence of alpine input into the graben as indicated by the carbonate content within the sediments, as well as by the changing distribution of heavy minerals. The Pliocene sediments in the graben zone are predominantly fine-grained. Sandy clays alternate with fine to medium sands and some peat layers. Gravel layers occur only sporadically (Hagedorn \& Boenigk 2008).

\section{Methods}

\subsection{Downhole Logging}

In the majority of boreholes downhole logging was conducted by the Leibniz Institute for Applied Geophysics (LIAG), Hannover; an exception is Hüttenfeld, where downhole logging was performed by the Geological Survey of Hessen (HLUG). The number of measured geophysical parameters at each site differs significantly: the most complete borehole measurement data sets were obtained at the Heidelberg and Viernheim sites, but Pfungstadt comprises a slightly reduced number of downhole measurements. At the Ludwigshafen, Stadtwerke Viernheim and Hüttenfeld sites only gamma ray logs (GR) were run.

The downhole logging in Heidelberg, Viernheim and Pfungstadt was conducted in several sections because of problems within these less lithified sediments during drilling. This means that up to five logging campaigns were necessary to complete downhole logging. The borehole diameter generally decreases in stages (e.g. from $244 \mathrm{~mm}$ to $200 \mathrm{~mm}$ to $150 \mathrm{~mm}$ ) with increasing depth. The steps coincide with each logging campaign.

The downhole measurements can be differentiated into radioactive methods (density, neutron porosity, spectral gamma ray including gamma ray, potassium, thorium and uranium); acoustic methods (sonic velocity and acoustic borehole televiewer); electrical methods (dual laterolog resistivity, dipmeter); magnetic methods (magnetic susceptibility); and other methods (borehole diameter, temperature and salt content of the drilling mud).

Only those logs yielding information on the physical properties of the sediments, in particular on their grain size, were utilised for further 


\section{Heidelberg}
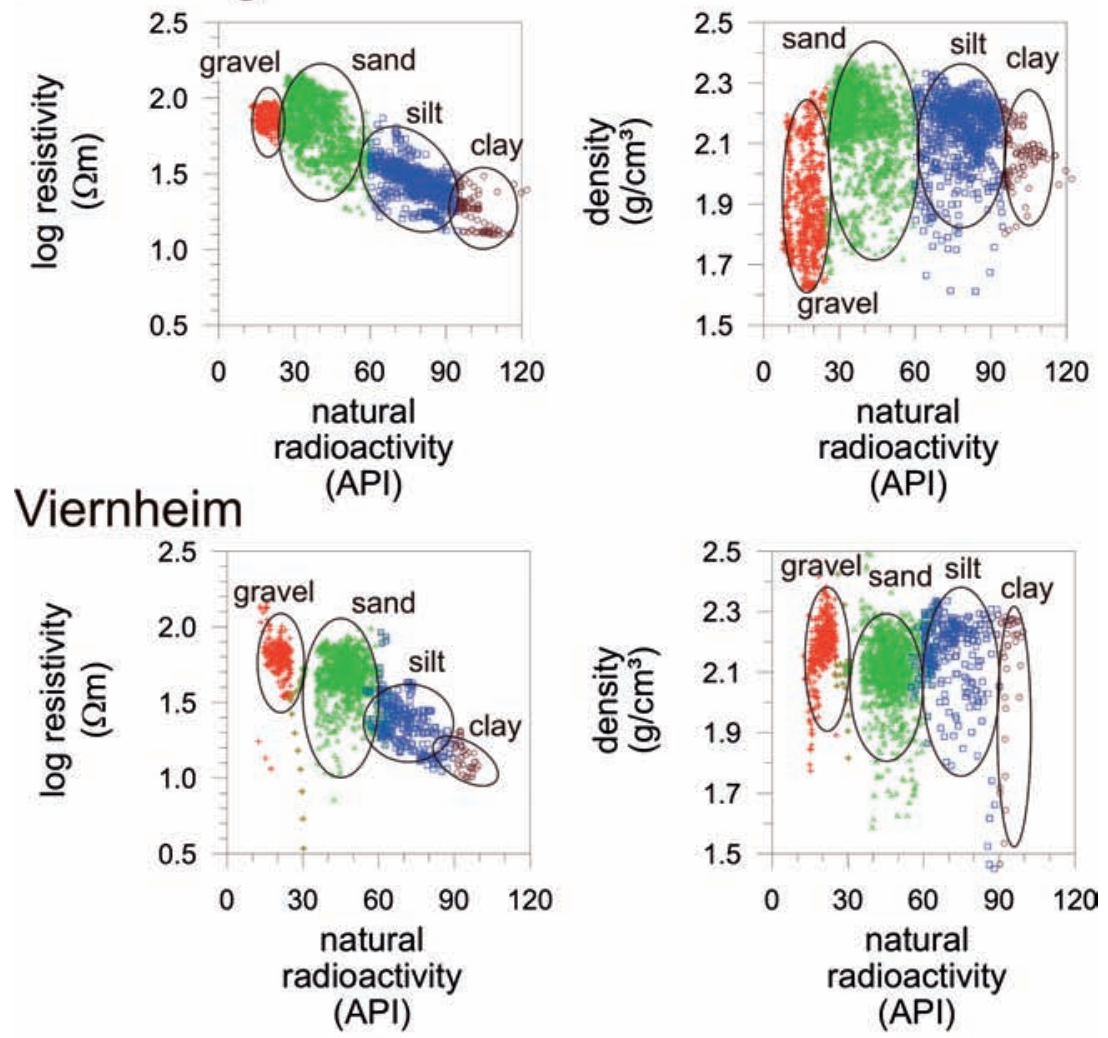

\section{Pfungstadt}

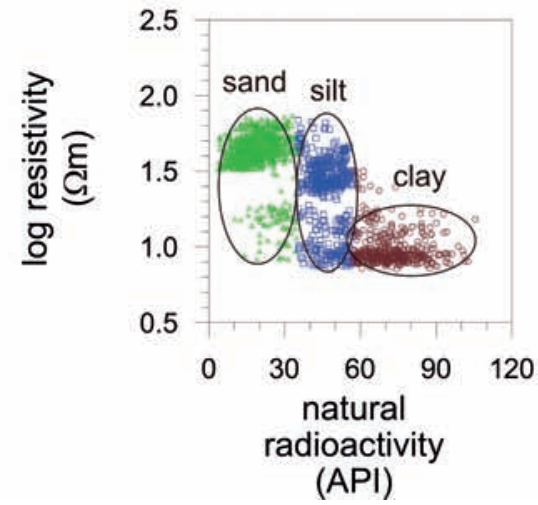

+ sandy gravel and pebbly sand

$\triangle$ sand

silt and clayey silt

clay and silty clay

Fig. 2: Crossplots of the parameters natural radioactivity vs. resistivity and vs. bulk density for the drill sites Heidelberg, Viernheim and Pfungstadt. The four lithologies differentiated from the cores (sandy gravel; pebbly sand; sand, silt and clayey silt; clay and silty clay) are marked.

Abb. 2: Crossplots der Parameter natürliche Radioaktivität gegen Widerstand bzw. natürliche Radioaktivität gegen Dichte für die Bohrlokationen Heidelberg, Viernheim und Pfungstadt. Darin eingetragen ist die Differenzierung der vier Lithologien der Kerne (sandiger Kies und kiesiger Sand, Sand, Schluff und toniger Schluff sowie Ton und schluffiger Ton). 
interpretation. These logs are GR, density, neutron porosity, resistivity, susceptibility, and caliper (borehole diameter). The caliper reflects the actual borehole diameter during logging as compared to the drilling diameter. Any sections with high differences in borehole diameter must be interpreted with caution. The neutron porosity log measures only relative porosity values; no absolute porosity values can be given. Therefore, the unit a.u. is used below.

\subsection{Physical Properties}

The main objective of analysing physical properties is to characterise each lithology by its specific physical properties. For better comparison the mean value and the standard deviation for each lithology has been calculated (Table 2 and Appendix). The log data sets were corrected prior to interpretation; this includes deleting erroneous and negative values. Those sections preferably with homogeneous lithology as determined by core descriptions (HoselmanN 2008; WeIDENFELLER \& KNIPPING 2008) are then selected and corrected using crossplots. Cross-plotting logs is usually done to quantify lithology and empirical relationships often become evident (RIDER, 1996). Finally, the physical properties of each lithology are calculated from the most prominent downhole logs, which are GR, density, porosity, resistivity (far) and susceptibility.

\subsection{Hole-to-hole Correlation}

Changes in sediment thickness, and therefore in sediment input, can be quantified by holeto-hole correlation. This method comprises the synoptical comparison and connection of similar characteristic peaks and downhole log trends from adjacent sites. The correlation was performed using several logs (such as GR, susceptibility, porosity, density and resistivity), but most logs, except the GR log, were not measured at all sites and/or data variation is high. The correlation was therefore carried out on the GR $\log$ (Figures 3, 4 and 5), because of its low data scatter and characteristic log trends. RIDER (1996) pointed out that the GR $\log$ is used for correlation, because the "character' of the gamma ray log is repeatable, is not affected by compaction with depth, and gives some indication of lithology.

\subsection{Cluster Analysis}

The lithologies and resultant possible sediment provenances were determined using the statistical method of cluster analysis (Ward method of complete hierarchical linkage, Figure 5). The WINSTAT Statistic for Windows (Version 3.1) software application was employed for this purpose.

Cluster analysis is a multivariate statistical technique, which assesses the similarities between units based on the occurrence or absence of specific components within them. This analysis creates homogeneous (members are similar to one another) groups of variables, the clusters. The elements in a cluster have relatively small distances from each other and relatively larger distances from elements outside a cluster (Davis 1986; Backhaus et al. 1996). Cluster analysis differentiates groups characterised by their physical properties. The number of clusters is determined using a tree-like structure, the dendrogram, which visualises the similarity of clusters (MOLINE et al. 1992, Fricke \& SCHÖN 1999). The dendrogram is cut horizontally at any level to create groups, which are compared to core data, and the most appropriate grouping level is chosen (RIDER 1996).

The cluster analysis is performed for four locations simultaneously, allowing a comparison of the resulting clusters between the drill sites. The maximum number of parameters used for calculating the clusters in Heidelberg and Viernheim is six (Table 2). However, the number of logging parameters is reduced at the two other locations: in Pfungstadt four parameters were measured and in Ludwigshafen only one. Cluster analysis was not performed for the Hüttenfeld and Stadtwerke Viernheim boreholes, because of an insufficient number of measured geophysical parameters. 
Table 2: Overview of the logged parameters at each drill site. $x$ : this parameter was logged at this site. -: this parameter was not logged.

Tab. 2: Überblick über die gemessenen Parameter an jeder Bohrlokation. x: der Parameter wurde an dieser Bohrlokation gemessen. -: der Parameter wurde nicht gemessen.

\begin{tabular}{lcccccc}
\hline Drill site & $\begin{array}{c}\text { SGR } \\
(\mathrm{API})\end{array}$ & $\begin{array}{c}\text { Density } \\
\left(\mathrm{g} / \mathrm{cm}^{3}\right)\end{array}$ & $\begin{array}{c}\text { Neutron } \\
\text { porosity } \\
(\text { a.u. })\end{array}$ & $\begin{array}{c}\text { Resistivity } \\
(\Omega \mathrm{m})\end{array}$ & $\begin{array}{c}\text { Suscepti-bility } \\
\left(10^{-4} \mathrm{SI}\right)\end{array}$ & $\begin{array}{c}\text { Borehole } \\
\text { diameter } \\
(\mathrm{mm})\end{array}$ \\
\hline Pfungstadt & $\mathrm{x}$ & - & $\mathrm{x}$ & - & $\mathrm{x}$ & $\mathrm{x}$ \\
Viernheim & $\mathrm{x}$ & $\mathrm{x}$ & $\mathrm{x}$ & $\mathrm{x}$ & $\mathrm{x}$ & $\mathrm{x}$ \\
Ludwigshafen & $\mathrm{x}$ & - & - & - & - & - \\
Heidelberg & $\mathrm{x}$ & $\mathrm{x}$ & $\mathrm{x}$ & $\mathrm{x}$ & $\mathrm{x}$ & $\mathrm{x}$ \\
\hline
\end{tabular}

\section{Results}

\subsection{Physical Properties}

\subsubsection{Crossplots}

The crossplots of the most significant parameters characterising the physical properties of the cored lithologies are described (Figure 2): the most useful logs for this purpose are GR, resistivity, and density in Heidelberg and Viernheim, and GR and resistivity in Pfungstadt. The other locations did not use these logs and, hence, crossplots cannot be plotted. Four groups of lithologies are differentiated based on the description of core lithologies: (1) sandy gravel and pebbly sand, (2) sand, (3) silt and clayey silt and (4) clay and silty clay.

The natural radioactivity (GR) vs. resistivity crossplots from Heidelberg, Viernheim and Pfungstadt (Figure 2, left column) are compared. The crossplots of the three locations show almost the same log trends: a strong negative correlation between GR and log resistivity. There, (a) sandy gravel and pebbly sand and (b) sand are characterised by low GR values (0-55 API) and high log resistivity values (0.8$2.3 \Omega \mathrm{m})$. However, the $\log$ resistivity values of sandy gravel and pebbly sand differ between boreholes: in Heidelberg the values are slightly higher (1.3-2.3 $\Omega \mathrm{m})$ than in Viernheim (1.1-2.1 $\Omega \mathrm{m})$ and considerably higher than in Pfungstadt (0.8-1.9 $\Omega \mathrm{m})$. At all sites (a) silt and clayey silt and (b) clay and silty clay are characterised by high GR values (55-130 API) and low $\log$ resistivity values (0.8-1.8 $\Omega \mathrm{m})$. It is important to note that in Pfungstadt the downhole logs were measured within the liner and, as a result, the downhole logs, especially the GR values, are significantly lower. If this is corrected, the boundary values for each lithology are also corrected. However, the clay resistivity values for Pfungstadt are much lower than at the other sites.

The crossplots GR vs. density for Heidelberg and Viernheim (Figure 2, right column) are plotted. In Heidelberg, the density data differ between the sandy gravel and pebbly sand (1.6$2.2 \mathrm{~g} / \mathrm{cm}^{3}$ ) and the sand, silt and clayey silt, and clay and silty clay lithologies $\left(1.8-2.4 \mathrm{~g} / \mathrm{cm}^{3}\right)$. In contrast, almost all Viernheim lithologies display similar density data $\left(1.8-2.4 \mathrm{~g} / \mathrm{cm}^{3}\right)$. An exception is sandy gravel and pebbly sand, which are characterised by slightly enhanced values (1.9-2.4 g/ $\left.\mathrm{cm}^{3}\right)$. Unfortunately, no density data were recorded in Pfungstadt. One possible reason why sandy gravel and pebbly sand display lower density values in Heidelberg than in Viernheim may be a lesser degree of compaction in Heidelberg due to rapid sedimentation from the River Neckar. This conclusion coincides 
Appendix: Physical properties (mean value and standard deviation) of the six investigated boreholes within the Heidelberg basin. The boreholes are sorted according to distance from the margin towards the centre of the Heidelberg Basin. The number of data points varies as a function of the logging parameter.

\begin{tabular}{|l|c|c|c|c|}
\hline Pfungstadt & $\begin{array}{c}\text { Sandy gravel, } \\
\text { pebbly sand }\end{array}$ & Sand & $\begin{array}{c}\text { Silt, } \\
\text { clayey silt }\end{array}$ & $\begin{array}{c}\text { Clay, } \\
\text { silty clay }\end{array}$ \\
\hline Number of data points & 0 & $957-1000$ & $197-522$ & $420-428$ \\
\hline & - & $20 \pm 7$ & $47 \pm 6$ & $72 \pm 10$ \\
\hline GR $(\mathrm{API})$ & - & $1.61 \pm 0.16$ & $1.36 \pm 0.24$ & $0.98 \pm 0.09$ \\
\hline Log resistivity $(\Omega \mathrm{m})$ & - & $0.65 \pm 0.06$ & $0.62 \pm 0.05$ & $0.63 \pm 0.06$ \\
\hline Log susceptibility $\left(10^{-4} \mathrm{SI}\right)$ & - & & \\
\hline
\end{tabular}

\begin{tabular}{|l|c|c|c|c|}
\hline Ludwigshafen & $\begin{array}{c}\text { Sandy gravel, } \\
\text { pebbly sand }\end{array}$ & Sand & $\begin{array}{c}\text { Silt, } \\
\text { clayey silt }\end{array}$ & $\begin{array}{c}\text { Clay, } \\
\text { silty clay }\end{array}$ \\
\hline Number of data points & 828 & 4108 & 263 & 806 \\
\hline & & & & \\
\hline GR (API) & $20 \pm 3$ & $39 \pm 8$ & $68 \pm 6$ & $102 \pm 9$ \\
\hline
\end{tabular}

\begin{tabular}{|l|c|c|c|c|}
\hline Hüttenfeld & $\begin{array}{c}\text { Sandy gravel, } \\
\text { pebbly sand }\end{array}$ & Sand & $\begin{array}{c}\text { Silt, } \\
\text { clayey silt }\end{array}$ & $\begin{array}{c}\text { Clay, } \\
\text { silty clay }\end{array}$ \\
\hline Number of data points & 737 & 450 & 163 & 47 \\
\hline & & & & \\
\hline GR (API) & $24 \pm 5$ & $37 \pm 4$ & $59 \pm 6$ & $77 \pm 7$ \\
\hline
\end{tabular}

\begin{tabular}{|l|c|c|c|c|}
\hline Viernheim & $\begin{array}{c}\text { Sandy gravel, } \\
\text { pebbly sand }\end{array}$ & Sand & $\begin{array}{c}\text { Silt, } \\
\text { clayey silt }\end{array}$ & $\begin{array}{c}\text { Clay, } \\
\text { silty clay }\end{array}$ \\
\hline Number of data points & $325-466$ & $1114-1165$ & $261-324$ & $38-110$ \\
\hline & & & & \\
\hline GR (API) & $20 \pm 3$ & $47 \pm 7$ & $70 \pm 8$ & $109 \pm 15$ \\
\hline Density $\left(\mathrm{g} / \mathrm{cm}^{3}\right)$ & $2.20 \pm 0.12$ & $2.12 \pm 0.13$ & $2.16 \pm 0.14$ & $2.11 \pm 0.23$ \\
\hline Neutron porosity (a.u.) & $35 \pm 11$ & $38 \pm 11$ & $42 \pm 12$ & $46 \pm 14$ \\
\hline Log resistivity $(\Omega \mathrm{m})$ & $1.75 \pm 0.29$ & $1.60 \pm 0.36$ & $1.37 \pm 0.16$ & $1.15 \pm 0.09$ \\
\hline Log susceptibility $\left(10^{-4} \mathrm{SI}\right)$ & $0.65 \pm 0.26$ & $0.80 \pm 0.43$ & $0.87 \pm 0.67$ & $0.71 \pm 0.45$ \\
\hline
\end{tabular}

\begin{tabular}{|l|c|c|c|c|}
\hline Stadtwerke Viernheim & $\begin{array}{c}\text { Sandy gravel, } \\
\text { pebbly sand }\end{array}$ & Sand & $\begin{array}{c}\text { Silt, } \\
\text { clayey silt }\end{array}$ & $\begin{array}{c}\text { Clay, } \\
\text { silty clay }\end{array}$ \\
\hline Number of data points & 774 & 677 & 552 & 132 \\
\hline & & & & \\
\hline GR (API) & $27 \pm 5$ & $42 \pm 4$ & $58 \pm 5$ & $77 \pm 6$ \\
\hline
\end{tabular}

\begin{tabular}{|l|c|c|c|c|}
\hline Heidelberg & $\begin{array}{c}\text { Sandy gravel, } \\
\text { pebbly sand }\end{array}$ & Sand & $\begin{array}{c}\text { Silt, } \\
\text { clayey silt }\end{array}$ & $\begin{array}{c}\text { Clay, } \\
\text { silty clay }\end{array}$ \\
\hline Number of data points & $409-1034$ & $1584-1661$ & $775-808$ & $99-110$ \\
\hline & & & & \\
\hline GR (API) & $15 \pm 5$ & $38 \pm 9$ & $78 \pm 9$ & $102 \pm 6$ \\
\hline Density $\left(\mathrm{g} / \mathrm{cm}^{3}\right)$ & $1.90 \pm 0.17$ & $2.16 \pm 0.13$ & $2.14 \pm 0.11$ & $2.06 \pm 0.09$ \\
\hline Neutron porosity (a.u.) & $41 \pm 18$ & $33 \pm 5$ & $38 \pm 5$ & $43 \pm 8$ \\
\hline Log resistivity $(\Omega \mathrm{m})$ & $1.87 \pm 0.06$ & $1.86 \pm 0.19$ & $1.44 \pm 0.11$ & $1.25 \pm 0.11$ \\
\hline Log susceptibility $\left(10^{-4} \mathrm{SI}\right)$ & $0.66 \pm 0.05$ & $0.57 \pm 0.06$ & $0.65 \pm 0.11$ & $0.67 \pm 0.06$ \\
\hline
\end{tabular}




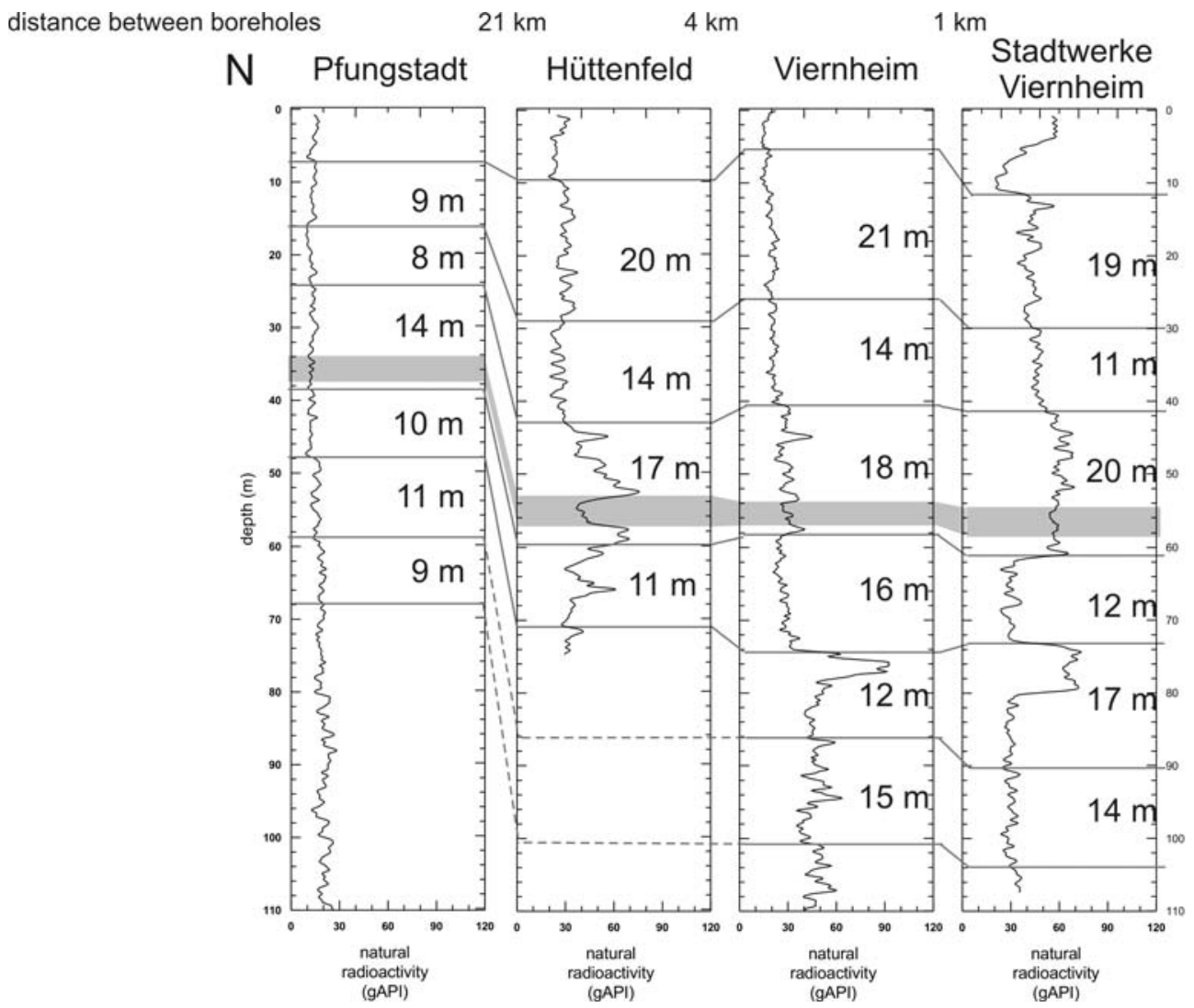

Fig. 3: Hole-to-hole correlation using the natural radioactivity log (smoothed) of the drill sites around Viernheim (Viernheim, Stadtwerke Viernheim and Hüttenfeld) and the Pfungstadt borehole. The grey horizontal lines mark the sediment package, characterised by its specific log trends and peaks. The grey boxes mark the detailed correlation of this randomly selected sediment package.

Abb. 3: Bohrloch-Bohrloch Korrelation unter Verwendung des Logs der natürlichen Radioaktivität (geglättet) der Bohrlokationen um Viernheim (Viernheim, Stadtwerke Viernheim und Hüttenfeld) sowie Pfungstadt. Die graue horizontale Linie markiert das Sedimentpaket, das charakterisiert ist durch seine besonderen Logtrends und Spitzen. Die grauen Kästchen markieren die detaillierte Korrelation dieser zufällig ausgesuchten Sedimentpakete.

with the highest sediment thickness at the basin centre. Another reason may be the mineralogy of the sediments at the different drill sites.

Comparing the results of both crossplots shows that the GR vs. resistivity crossplot implies that the fine-grained sediments are characterised by low resistivity values, which suggests high conductivity possibly caused by high water content, salinity and/or porosity. In the GR vs. density crossplot the coarser-grained sediments are characterised by both low and high density values and the finer-grained ones by high density values. This suggests that the high density values in fine-grained sediments may be caused by mineralogy and/or a higher degree of compaction.

\subsubsection{Statistics of Physical Properties}

The physical properties of the Upper Rhine 


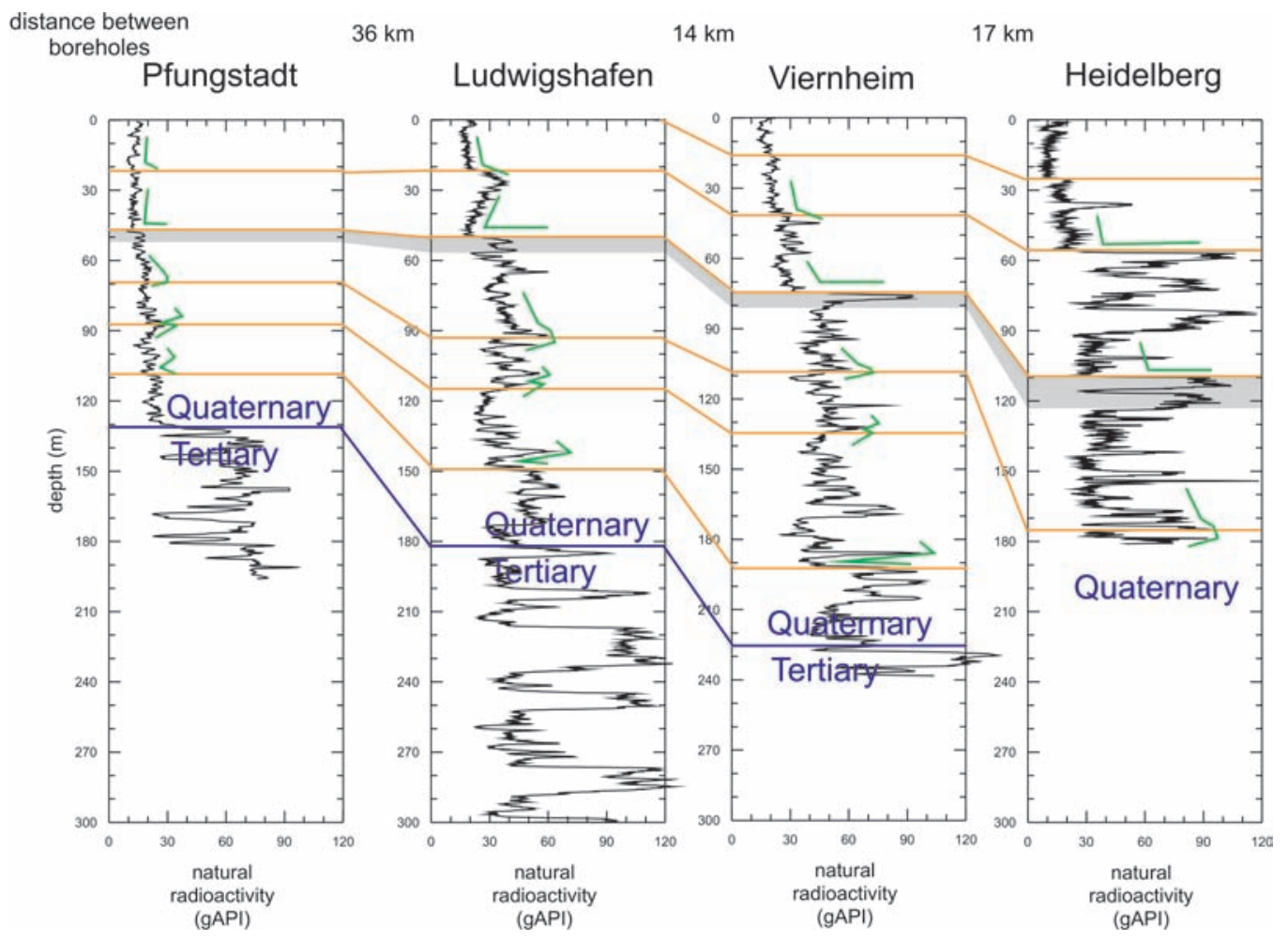

Fig. 4: Hole-to-hole correlation using the GR log from the drill sites within the Heidelberg Basin (Pfungstadt, Ludwigshafen, Viernheim, and Heidelberg). The lowermost blue horizontal lines mark the Pliocene-Pleistocene boundary as described in the cores. The red horizontal lines mark the sediment package, characterised by specific log trends (marked with vertical line) and peaks. The green lines mark the characteristic log trends. The grey boxes mark the detailed correlation of one randomly selected sediment package.

Abb. 4: Bohrloch-Bohrloch Korrelation unter Verwendung des GR Logs der Bohrlokationen im Heidelberger Becken (Pfungstadt, Ludwigshafen, Viernheim und Heidelberg). Die unterste blaue, horizontale Linie markiert die Pliozän-Pleistozän Grenze wie sie in den Kernen beschrieben wurde. Die anderen roten, horizontalen Linien markieren jeweils das Sedimentpaket, das charakterisiert ist durch seine besonderen Logtrends (markiert mit vertikaler Linie) und Spitzen. Die grünen Linien markieren die charakteristischen Logtrends. Die grauen Kästchen markieren die detaillierte Korrelation dieser zufällig ausgesuchten Sedimentpakete.

Graben were computed to determine both their characteristics and their changes according to location within the Heidelberg Basin (see Appendix). The physical properties are described using Viernheim as an example (Table 3). Principally, natural radioactivity reflects the grain size: the higher the natural radioactivity values, the higher the clay content of the sediment. The density and log resistivity values decrease and the neutron porosity values increase with increasing clay content (from sandy gravel to clay). Again, this may imply a decreasing degree of compaction from the coarser-grained to the finer-grained sediments. The log susceptibility values vary with grain size, because this parameter mainly reflects an overall change in sediment input.

A number of important trends are observed by comparing the physical properties of all lithologies within the Heidelberg Basin (see Appendix). Overall, it must be kept in mind that the lithologies were defined for each site separately. This leads to more or less significant differences in GR values between 
Table 3: Physical properties of the Viernheim sediments derived from logging data. The number of data points is given for quality control.

Tab. 3: Die physikalischen Eigenschaften der Sedimente in Viernheim, die aus den Bohrlochmessungen abgeleitet wurden. Die Anzahl der Messdaten wird zur Qualitätskontrolle angegeben.

\begin{tabular}{lcccc}
\hline Viernheim & $\begin{array}{c}\text { Sandy gravel, } \\
\text { pebbly sand }\end{array}$ & Sand & $\begin{array}{c}\text { Silt, } \\
\text { clayey silt }\end{array}$ & $\begin{array}{c}\text { Clay, } \\
\text { silty clay }\end{array}$ \\
\hline Number of data points & $325-466$ & $1114-1165$ & $261-324$ & $38-110$ \\
Natural radioactivity (API) & $20 \pm 3$ & $47 \pm 7$ & $70 \pm 8$ & $109 \pm 15$ \\
Density (g/cm ${ }^{3}$ ) & $2.20 \pm 0.12$ & $2.12 \pm 0.13$ & $2.16 \pm 0.14$ & $2.11 \pm 0.23$ \\
Neutron porosity (a.u.) & $35 \pm 11$ & $38 \pm 11$ & $42 \pm 12$ & $46 \pm 14$ \\
Log resistivity $(\Omega \mathrm{m})$ & $1.75 \pm 0.29$ & $1.60 \pm 0.36$ & $1.37 \pm 0.16$ & $1.15 \pm 0.09$ \\
Log susceptibility $\left(10^{-4} \mathrm{SI}\right)$ & $0.65 \pm 0.26$ & $0.80 \pm 0.43$ & $0.87 \pm 0.67$ & $0.71 \pm 0.45$ \\
\hline
\end{tabular}

the boreholes and the composition of each lithology varies among the drill sites. Sand is taken as an example: varying GR values at the different drill sites imply different amounts of fine-, medium- and coarse-grained sand and a varying amount of clay within the sediment matrix. This is valid for all four lithologies. However, the bulk density values of all drill sites are comparable, but the GR values differ significantly between Heidelberg and Viernheim. Reasons may be different mineralogical compositions caused by different sediment provenances.

\subsubsection{Sediment Thickness}

The crossplots facilitate a differentiation of lithologies. The thickness of the sediment in each lithology is determined from this (Table 4). The main objective is to quantify the changes in sediment composition from margin to centre in the Heidelberg Basin and from south to north in the Upper Rhine Graben. In Pfungstadt (at the northern margin of the basin) the drilled and logged sediments are mainly composed of sand (sediment thickness $100.0 \mathrm{~m}$ ). Pfungstadt is located furthest north of all boreholes in the Upper Rhine Graben. Thus, input from the
Odenwald is high and less influenced by the River Rhine due to its distance from the Rhine Graben. This borehole contains the highest amount of clay and silty clay $(45 \mathrm{~m})$, which may be a result of its location at the northern margin of the basin with its fine-grained sediment input. In comparison, there are only small differences to the other drill site in the basin margin at Ludwigshafen. The lithology with the largest sediment thickness is sand $(205 \mathrm{~m})$, and the smallest is silt and clayey silt (13 m). Finally, the borehole at Heidelberg (at the centre of the Heidelberg Basin) is characterised by very thick sandy sediments $(82 \mathrm{~m})$ and much lesser clay and silty clay $(4 \mathrm{~m})$. These observations reflect the input of coarser-grained sediments from the River Neckar and almost no influence by the River Rhine.

Overall, it must be kept in mind that the total drilling depth and total logging depths differ locally due to borehole collapse. The most significant example is Hüttenfeld, where the total drilling depth amounts to $99 \mathrm{~m}$ and, in contrast, the total logging depth is only $75 \mathrm{~m}$. This leads to incomplete analysis of lithologic composition, which underestimates the less compacted lithologies such as sand and gravel. 
Table 4: Overview of sediment thicknesses in all boreholes differentiated according to the four cored lithologies. The boreholes are sorted according to distance from the margin to the centre of the Heidelberg Basin. The bold numbers are the highest and lowest values of each drill site, respectively.

Tab. 4: Überblick über die Sedimentmächtigkeiten an allen Bohrlokationen, die entsprechend den vier in den Kernen erbohrten Lithologien differenziert wurden. Die Bohrlokationen sind nach ihrer Entfernung vom Beckenrand bis zum Zentrum des Heidelberger Beckens sortiert. Die fett gedruckten Zahlen stellen die jeweils höchsten und tiefsten Werte für jede Bohrlokation dar.

\begin{tabular}{|l|c|c|c|c|c|}
\hline \multirow{2}{*}{} & \multirow{2}{*}{$\begin{array}{c}\text { Logging } \\
\text { depth }(\mathrm{m})\end{array}$} & $\begin{array}{c}\text { Sandy gravel and } \\
\text { pebbly sand }\end{array}$ & Sand & $\begin{array}{c}\text { Silt and } \\
\text { clayey silt }\end{array}$ & $\begin{array}{c}\text { Clay and silty } \\
\text { clay }\end{array}$ \\
\cline { 3 - 6 } Pfungstadt & 198 & $\mathbf{0}$ & $\mathbf{1 0 0}$ & 53 & 45 \\
\hline Ludwigshafen & 300 & 41 & $\mathbf{2 0 5}$ & $\mathbf{1 3}$ & 40 \\
\hline Hüttenfeld & 75 & $\mathbf{3 8}$ & 24 & 9 & $\mathbf{4}$ \\
\hline Viernheim & 238 & 53 & $\mathbf{1 3 3}$ & 38 & 15 \\
\hline $\begin{array}{l}\text { Stadtwerke } \\
\text { Viernheim }\end{array}$ & 108 & $\mathbf{3 9}$ & 34 & 28 & $\mathbf{6 . 9}$ \\
\hline Heidelberg & 175 & 50 & $\mathbf{8 2}$ & 39 & $\mathbf{4 . 1}$ \\
\hline
\end{tabular}

\subsection{Sediment Provenance}

\subsubsection{Viernheim}

\subsubsection{Hole-to-hole Correlation}

Although Hüttenfeld and Pfungstadt are separated by $21 \mathrm{~km}$, the resulting correlation between all four drill sites around Viernheim, as determined by hole-to-hole correlation, is good (Figure 3). The thicknesses of the linemarked sediment sections at the drill sites around Viernheim do not vary significantly, but decrease slightly towards Pfungstadt.

As an example, one randomly selected sediment package is picked and marked grey (Figure 3). Surprisingly, the thickness of this sediment section increases from Stadtwerke Viernheim and Viernheim to Hüttenfeld and Pfungstadt. The selected sediment section is composed of sand to silt and clayey silt and is about $2 \mathrm{~m}$ thick in Viernheim and Stadtwerke Viernheim. This increases to $2.5 \mathrm{~m}$ in Hüttenfeld, which may be a result of local sediment accumulation. On the other hand, the two drill sites around Viernheim (Viernheim and Stadtwerke Viernheim) may be influenced by erosion or sediment compaction. The sediment thickness in Pfungstadt decreases slightly to $2 \mathrm{~m}$, due to different, possibly local sediment input from Odenwald.

\subsubsection{Cluster Analysis}

The cluster analysis for the drill sites around Viernheim could not be performed due to the absence of several geophysical parameters measured downhole.

\subsubsection{Heidelberg Basin}

\subsubsection{Hole-to-hole Correlation}

Overall, there is good correlation between all four drill sites determined from hole-to-hole measurements (Figure 4), despite the large distances between the investigated sites ( $36 \mathrm{~km}$ between Pfungstadt and Ludwigshafen). As anticipated, the thickness of correlated sediment 


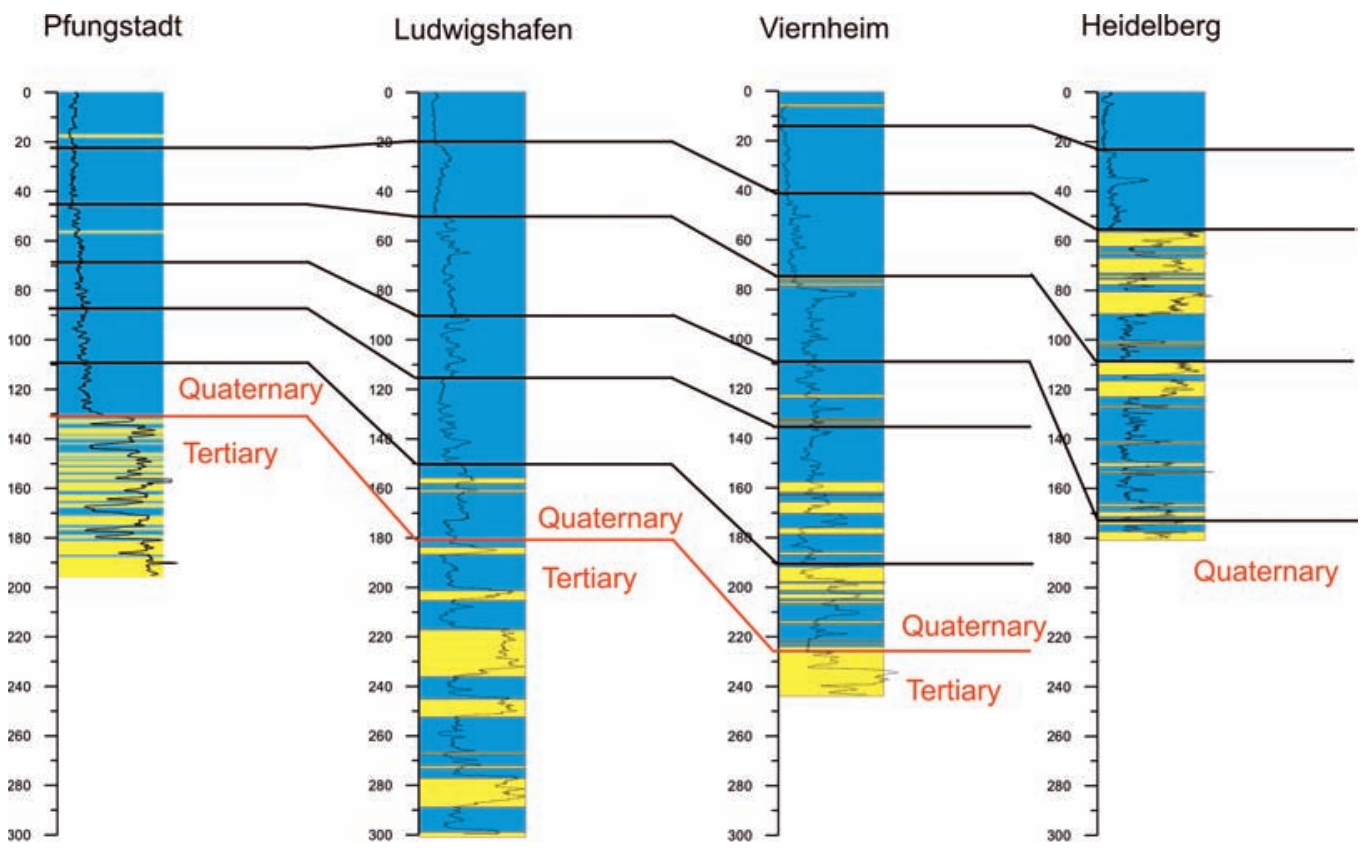

Fig. 5: Results of the cluster analysis of the Ludwigshafen, Viernheim, Pfungstadt, and Heidelberg boreholes. The characteristic GR log and the Pliocene-Pleistocene boundary for each site are plotted.

Abb. 5: Ergebnisse der Clusteranalyse der Bohrlokationen Ludwigshafen, Viernheim, Pfungstadt und Heidelberg. Darin sind das charakteristische GR Log und die Pliozän-Pleistozän Grenze für jede Bohrlokation dargestellt.

layers is greatest in Heidelberg, which is located in the subsidence centre of the Heidelberg Basin, and lowest in Pfungstadt located at the northern margin of the basin.

Again, one sediment package is chosen at random to determine the changes in sediment provenance (Figure 4). The following description of the sediment package is based on a profile from the two margins of the basin (Pfungstadt and Ludwigshafen) to its centre (Heidelberg). The log trends and the thickness of the chosen sediment package are quite similar in Pfungstadt and Ludwigshafen (sediment composition: sandy gravel and pebbly sand). In Viernheim, the sediments are fine-grained in the upper part and coarse-grained in the lower part. Thus, additional fine-grained input did occur. Finally, in Heidelberg, the sediment composition changes again: the sediments are mainly composed of clay and only small amounts of sand occur. Surprisingly, the log characteristics are quite si- milar to the curve trends at Ludwigshafen, but with enhanced clay content. Sediment transport to Viernheim is influenced by a different sediment provenance (such as the River Rhine) or is blocked by a local sediment barrier.

\subsubsection{Cluster Analysis}

The clusters are computed for each drill site, separately defining the number of clusters (Figure 5). Overall, this number was defined as two, because the other clusters contained only a few data points or reflect erroneous values (e.g., at the top or the bottom of the borehole). The determined clusters were interpreted as different lithologies reflecting two different sediment provenances: The first cluster (dark coloured) with low GR ( $34 \pm 13$ API), high log resistivity $(1.60 \pm 0.33 \Omega \mathrm{m})$ and low log susceptibility $\left(0.67 \pm 0.2110^{-4} \mathrm{SI}\right)$ values reflects sediments rich in sandy gravel and pebbly sand to sand, 
which probably originate from the River Neckar (proximal deposition from Odenwald). The second cluster (light coloured) with high GR (81 \pm 20 API), low log resistivity $(1.29 \pm 0.45 \Omega \mathrm{m})$ and high $\log$ susceptibility $\left(0.77 \pm 0.5210^{-4} \mathrm{SI}\right)$ values mainly contains sediments rich in clay, which were probably deposited from the River Rhine (distal deposition from the Alps, Black Forest and Vogues). The other parameters (density, borehole diameter, and neutron porosity) have similar values for both clusters. Transferring the hole-to-hole correlation to the results of the cluster analysis shows clear differences in sediment provenances. These observations lead to the assumption that overall sediment depositions are similar, but differ in detail influenced by two different sediment provenances River Neckar (Cluster 1) and River Rhine (Cluster 2).

\section{Conclusions and Discussion}

The interpretation of downhole logs leads to the following conclusions: the physical properties of sediments derived from logs and cores can be quantified and the results compared. Four groups of lithologies can be differentiated using the natural radioactivity (GR) vs. resistivity and GR vs. density crossplots: (1) sandy gravel and pebbly sand, (2) sand, (3) silt and clayey silt and (4) clay and silty clay. The results of the GR vs. resistivity crossplots imply high conductivity possibly caused by high water content, salinity and/or porosity. In the GR vs. density crossplot, the coarser-grained sediments are characterised by both low and high density values and the finer-grained sediments (silt, clayey silt, clay and silty clay) by high density values. This suggests that the high density values in fine-grained sediments may be caused by mineralogy and/or a higher degree of compaction.

Interpretation of the hole-to-hole correlation displays a coincidence of sediment provenances around Viernheim (close to the centre of the Heidelberg Basin) and only small changes towards Pfungstadt (located at the northern margin of the basin). Furthermore, this correlation shows the anticipated changes in sediment layer thickness from Pfungstadt (smallest thickness) to Heidelberg (greatest thickness at the basin centre). Additionally, the statistical method of cluster analysis confirms two main sediment provenances interpreted as deposits from the Rivers Rhine and Neckar. However, the results of the hole-to-hole correlation and the cluster analysis differ. This implies different contributions of a single sediment package to one of the two sediment provenances. The problem posed here is that both methods are based on assumptions and more interpretation is necessary: hole-to-hole correlation is a visual method, very detailed and based on the assumption that the GR log is the most significant $\log$, because it mainly describes the sediment composition. On the other hand, the cluster analysis needs a predefined number of clusters and must be interpreted carefully.

More investigations are required to determine absolute ages in the investigated boreholes in order to confirm and/or critically test our visual and statistics-based hole-to-hole correlation and the interpreted sediment provenances. Sedimentological interpretations should be incorporated in our small-scale observations and expansion to a basin-scale analysis should follow.

Additionally, data acquired after deepening of the Heidelberg drill site in spring 2008 to an end depth of $500 \mathrm{~m}$ should be integrated in further studies, which are important in terms of the Tertiary-Quaternary boundary and the changes in sediment thickness at the drill sites.

\section{Acknowledgements}

We would like to thank Dr. C. Hoselmann, Dr. M. Weidenfeller and Dr. D. Ellwanger from the Geological Surveys of Hessen, Rheinland Pfalz and Baden-Württemberg for intensive discussions and general support. One anonymous reviewer improved the paper significantly - thanks for your effort.

\section{References}

Backhaus, K.,Erikson, B., Plinke, W., SchuchardFicher, C. \& WeIBer, R. (1996): Multivariate 
Analysemethoden: Eine anwendungsorientierte Einführung. - 591 p.; Berlin (Springer).

BARTZ, J. (1974): Die Mächtigkeit des Quartärs im Oberrheingraben. - In: Illies, J. H. \& Fuchs, K. (eds.): Approaches to Taphrogenesis. - InterUnion Commission on Geodynamics Scientific Report, 8: 78-87; Stuttgart (Schweizerbart).

Behrmann, J. H., Hermann, O., Horstmann, M., Tanner, D. C. \& Bertrand, G. (2003): Anatomy and kinematics of oblique continental rifting revealed: A three-dimensional case study of the southeast Upper Rhine Graben (Germany). -AAPG Bulletin, 87 (7): 1105-1121.

Clague, J. (2006): Open letter to INQUA Executive Committee. - Quaternary International, 154/ 155: 158-159.

Davis, J. C. (1986): Statistics and Data Analysis in Geology. - 646 p.; New York (Wiley).

Ellwanger, D., Bibus, E., Bludau, W., Kösel, M. \& Merkt, J. (1995): Baden-Württemberg. - In: BENDA, L. (ed.): Das Quartär Deutschlands: 255295; Stuttgart (Bornträger).

Ellwanger, D., Gabriel, G., Hoselmann, C., LämmermanN-BARThel, J. \& Weidenfeller, M. (2005): The Heidelberg Drilling Project (Upper Rhine Graben, Germany). - Quaternaire, 16 (3): 191-199.

Fetzer, K. D., Larres, K., Sabel, K.-J., Spies, E.-D. \& Weidenfeller, M. (1995): Hessen, Rheinland-Pfalz, Saarland. - In: Benda, L. (ed.): Das Quartär Deutschlands, 220-254; Stuttgart (Bornträger).

Fricke, S. \& SCHÖN, J. (1999): Praktische Bohrlochgeophysik. - 254 p.; Stuttgart (Enke).

GibBard, P.L. (2004): Quaternary ... now you see it, now you don't. - Quaternary International, 129: 89-91.
Gibbard, P.L., Smith, A.G., Zalasiewicz, J.A., Barry, T.L., Cantrill, D., Coe, A. L., Cope, J.C.W., Gale, A.S., Gregory, F.J., Powell, J.H., Rawson, P.F., Stone, P. \& Waters, C.N. (2005): What status for the Quaternary? - Boreas, 34: 1-6.

Hagedorn, E.-M. \& Boenigk, W. (2008): The Pliocene and Quaternary sedimentary and fluvial history in the Upper Rhine Graben based on heavy mineral analyses. - Netherlands Journal of Geosciences - Geologie en Mijnbouw, 87 (1): 21-32.

Hoselmann, C. (2008): The Pliocene and Pleistocene fluvial evolution in the northern Upper Rhine Graben based on results of the research borehole at Viernheim (Hessen, Germany). - Eiszeitalter \& Gegenwart (Quaternary Science Journal), 57/3-4: 286-315.

Moline, G.R., Bahr, J.M., Drzewiecki, P.A. \& SHEPARD, L.D. (1992): Identification and characterisation of pressure seals through the use of wireline logs: a multivariate statistical approach. - Log Analyst, 33 (4): 362-372.

Preusser, F. (2008): Characterization and evolution of the River Rhine system. - Netherlands Journal of Geosciences - Geologie en Mijnbouw, 87 (1): 7-19.

RIDER, M. (1996): The Geological Interpretation of Well Logs. - 256 p.; Caithness (Whittles Publishing).

Weidenfeller, M. \& Knipping, M. (2008): Correlation of Pleistocene sediments from boreholes in the Ludwigshafen area, western Heidelberg Basin - Eiszeitalter \& Gegenwart (Quaternary Science Journal), 57/3-4: 270-285.

Westerhoff, W.E. (2008): The Rhine - a major fluvial record. - Netherlands Journal of Geosciences - Geologie en Mijnbouw, 87 (1): 3-5. 